\title{
Akuntabilitas dan Transparansi Pengelolaan Keuangan Objek Wisata Aling-Aling Waterfall Sebagai Pendapatan Tambahan Desa Sambangan
}

\author{
Nyoman Puja Astawa ${ }^{1 *}$, Ni Wayan Yulianita Dewi ${ }^{2}$ iD \\ 123 Jurusan Ekonomi dan Akuntansi, Universitas Pendidikan Ganesha, Singaraja, Indonesia \\ *astawapuja01@gmail.com ${ }^{l}$
}

\begin{abstract}
Abstrak
Penelitian ini bertujuan untuk memperoleh pemahaman mengenai (1) sistem pencatatan aliran kas masuk dan keluar pada Objek Wisata Aling-Aling Waterfall di Desa Sambangan, (2) memahami praktik akuntabilitas dan transparansi dalam pengelolaan keuangan Objek Wisata Aling-Aling Waterfall di Desa Sambangan, dan (3) alur proses pengelolaan keuangan pada Objek Wisata Aling-Aling Waterfall di Desa Sambangan. Penelitian ini menggunakan metode penelitian kualitatif. Pengumpulan data dilakukan dengan cara wawancara, observasi dan dokumentasi.Analisis data dilakukan dengan menggunakan model analisis data interaktif Miles dan Huberman. Analisis data terdiri dari tiga alur kegiatan yang terjadi secara bersamaan, yaitu; reduksi data, penyajian data dan penarikan kesimpulan atau verifikasi.Hasil penelitian ini menunjukkan (1) sistem pencatatan aliran kas masuk dan aliran kas keluar pada pengelolaan Objek Wisata Aling-Aling Waterfall belum dipisahkan antara buku kas masuk dan keluar. (2) Praktik akuntabilitas dan transparansi dalam pengelolaan keuangan Objek Wisata Aling-Aling Waterfall ditunjukkan dengan digelarnya pertemuan secara rutin dengan seluruh anggota kelompok guna membahas posisi keuangan kelompok serta penyetoran tanda bukti penjualan tiket kunjungan kepada pihak BUMDes. (3) Alur proses pengelolaan keuangan pada Objek Wisata Aling-Aling Waterfall dimulai dari BUMDes yang bertugas mengeluarkan tiket kunjungan, kemudian petugas TIC (Tourist Information Centre) bertugas untuk menjual tiket kunjungan kepada wisatawan. Pendapatan dari hasil penjualan tiket kunjungan ini setiap harinya akan disetorkan kepada Bendahara Kelompok Aling-Aling yang kemudian akan dikelola.
\end{abstract}

Kata Kunci: Pengelolaan Keuangan, Akuntabilitas, Transparansi

\section{Abstract}

This study aims to gain an understanding of (1) the recording system of cash inflows and outflows at the Aling-Aling Waterfall Tourism Object in Sambangan Village, (2) understanding the practice of accountability and transparency in financial management of the Aling-Aling Waterfall Tourism Object in Sambangan Village, and (3) the flow of the financial management process at the Aling-Aling Waterfall Tourism Object in Sambangan Village. This study used qualitative research methods. Data collection was done by means of interviews, observation and documentation. Data analysis was performed using the interactive data analysis model of Miles and Huberman. Data analysis consists of three activities that occur simultaneously, namely; data reduction, data presentation and drawing conclusions or verification. The results of this study indicate (1) the recording system of cash inflows and outflows in the management of the Aling-Aling Waterfall Tourism Object has not been separated between incoming and outgoing cash books. (2) The practice of accountability and transparency in the financial management of the Aling-Aling Waterfall Tourism Object is shown by holding regular meetings with all group members to discuss the group's financial position and deposit proof of sales of visiting tickets to BUMDes. (3) The flow of the financial management process at the Aling-Aling Waterfall Tourism Object starts with the BUMDes in charge of issuing visit tickets, then the TIC (Tourist Information Center) officer is in charge of selling visit tickets to tourists. The income from the sales of these visiting tickets will be deposited daily to the Treasurer of the AlingAling Group who will then be managed.A simple sentence is English contains a minimum of subject and predicate elements.

Keywords: Financial Management, Accountability, Transparency

History:
Received:
Revised: 26 Juni 2021
Accepted: 28 Juni 2021
Published: 30 Juni 2021

Publisher: Undiksha Press

Licensed: This work is licensed under

a Creative Commons Attribution 3.0 License

Accepted: 28 Juni 2021

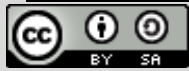




\section{Pendahuluan}

Akuntabilitas dan transparansi menjadi suatu hal yang sangat penting dalam pengelolaan keuangan di setiap organisasi, baik organisasi swasta, organisasi sektor publik, organisasi keagamaan, organisasi pemerintah maupun non pemerintah serta organiasi nirlaba. Suatu organisasi yang telah menerapkan akuntabilitas dan transparansi dalam pengelolaan keuangannya dapat dikatakan telah melakukan pertanggungjawaban kepada pihak yang memberi mandat atau amanah, pihak donatur, maupun kepada masyarakat pada umumnya. Tanpa diterapkannya prinsip akuntabilitas dan transparansi oleh pihak agen atau pengelola dapat menimbulkan ketidakpercayaan dari pihak pemberi amanah (principal) sehingga akan dapat mempengaruhi keberlangsungan dari organisasi tersebut.

Organisasi sektor publik seringkali dipahami sebagai organisasi yang tidak mencari laba atau non-profit. Banyak yang menganggap organisasi sektor publik sudah pasti nonprofit. Anggapan ini kurang tepat, karena organisasi sektor publik ada yang bertipe quasi non-profit. Organisasi sektor publik yang bertipe quasi non-profit bertujuan untuk meningkatkan kesejahteraan masyarakat dengan motif surplus (laba) sehingga terjadi keberlangsungan organisasi dan memberikan kontribusi pendapatan negara atau daerah. Oleh karena itu dapat dikatakan bahwa organisasi sektor publik bukan hanya organisasi sosial, bukan hanya organisasi nonprofit dan juga bukan hanya organisasi pemerintahan. Organiasi sektor publik tipe quasi non-profit memperoleh sumber pendanaan bisa dari investor pemerintah, investor swasta ataupun kreditor. Oleh karena sumber pendanaan organisasi yang diperoleh dari pihak lain, maka organisasi tersebut hendaknya bertanggungjawab kepada pihak yang memberi mandat atau amanah tersebut. Hubungan antara dua pelaku ekonomi yang memiliki kepentingan yang berbeda dijelaskan dalam teori agensi (agency theory).

Dalam teori keagenan (agency theory) menjelaskan tentang dua pelaku ekonomi yang memiliki kepentingan berbeda yaitu prinsipal dan agen (Ahmad \& Septriani, 2008). Hubungan keagenan merupakan suatu kontrak dimana satu atau lebih orang (prinsipal) memerintah orang lain (agen) untuk melakukan suatu jasa atas nama prinsipal serta memberi wewenang kepada agen membuat keputusan yang terbaik bagi prinsipal (Octalianna \& Rahayuningsih, 2013). Jika prinsipal dan agen memiliki tujuan yang sama maka agen akan mendukung dan melaksanakan semua yang diperintahkan oleh prinsipal.

Adanya pemisahaan antara fungsi kepemilikan (ownership) dan fungsi pengendalian (control) dalam hubungan keagenan sering menimbulkan masalah masalah keagenan (Sukmawati, Pujiningsih, \& Laily, 2016). Masalah keagenan tersebut timbul karena adanya konflik atau perbedaan kepentingan antara principal (pemilik perusahaan atau pihak yang memberikan mandat) dan agen (manajemen atau pihak yang menerima mandat). Penentuan kontrak yang paling efisien dapat membatasi konflik atau masalah keagenan. Namun demikian adanya kontrak yang efisien belum cukup untuk mengatasi masalah keagenan sehingga muncul konsep corporate governance (Ahmad \& Septriani, 2008).

Corporate governance merupakan tingkat elemen kunci dalam meningkatkan efisiensi ekonomis yang meliputi serangkaian hubungan antara manajemen perusahaan, dewan direksi, pemegang saham dan shareholder lainnya.Pentingnya mewujudkan Good Corporate Governance dengan menerapkan aspek transparansi dan akuntabilitas di dalam setiap organisasi merupakan fenomena yang harus dicermati oleh setiap organisasi agar organisasi tersebut dipercaya oleh para stakeholder. Jadi kesimpulannya GCG merupakan suatu tata kelola perusahaan yang mengatur hubungan antar stakeholders untuk meningkatkan keberhasilan usaha dan akuntabilitas perusahaan. Tidak hanya organisasi pemerintahan yang dituntut untuk menerapkan konsep akuntabilitas di dalam pelaporannya, namun organisasi non pemerintahan pun sudah mulai mendapat tuntutan untuk menyampaikan laporan keuangannya secara terbuka dan akuntabel. 
Salah satu contoh organisasi sektor publik non pemerintah yang diharapkan menerapkan prinsip akuntabilitas dan transparansi adalah kelompok ekonomi masyarakat. Organisasi/kelompok yang menjadi objek penelitian ini adalah Kelompok Aling-Aling sebagai organisasi pengelola Objek Wisata Air Terjun Aling-Aling/Aling-Aling Waterfall yang berlokasi di Desa Sambangan, Kecamatan Sukasada, Kabupaten Buleleng, Bali. Alasan peneliti melakukan penelitian di Objek Wisata Air Terjun Aling-Aling adalah : 1) Terdapat fenomena yaitu Kelompok Sadar Wisata Tunjung Mekar sebagai organisasi resmi tidak melakukan pengelolaan dan pelaporan keuangan objek wisata Aling-Aling Waterfall, justru kelompok yang bernaung dibawahnya yang melakukan pengelolaan keuangan. 2) Berdasarkan data kunjungan wisatawan tiga tahun terakhir, objek wisata Air Terjun AlingAling mengalami trend peningkatan yang cukup signifikan dalam jumlah kunjungan wisatawan.

Pengelolaan dana yang besar harus diikuti dengan penerapan akuntabilitas dan transparansi yang dilakukan oleh pihak Kelompok Aling-Aling sebagai agen/manajemen kepada masarayakat desa sebagai pemilik/principal. Selain dari alasan diatas, alasan lain peneliti memilih Objek Wisata Aling-Aling Waterfall sebagai objek penelitian karena adanya ketimpangan antara teori dan praktek di lapangan. Ketimpangan tersebut yakni pengelolaan keuangan Objek Wisata Aling-Aling Waterfall yang dilakukan oleh Kelompok Aling-Aling tidak melaporkan laporan keuangan kepada pemberi amanah (principal ) yaitu Pemerintah Desa Sambangan. Sedangkan teori yang dikemukakan oleh (Hehanussa, 2015)Pengelola (pemegang amanah) berkewajiban untuk mempertanggung jawabkan, menyajikan laporan, melaporkan laporan baik laporan maupun aktivitas dan kegiatan yang menjadi tanggung jawabnya kepada pemberi amanah.

Penelitian ini penting dilakukan disamping dari fenomena yang telah disebutkan di atas, penelitian mengenai akuntabilitas pengelolaan objek wisata masih jarang dilakukan, kebanyakan penelitian mengenai akuntabilitas dilakukan pada objek seperti dana desa dan pengelolaan keuangan rumah ibadah. Selain itu, peneliti menemukan fenomena bahwa Kelompok Aling-Aling sebagai pengelola (agent) tidak melaporkan laporan keuangannya kepada pihak pemerintah desa melalui BUMDes sebagai pemberi amanah (principle) sehingga terindikasi praktek akuntabilitas dan transparansi dalam pengelolaan Objek Wisata Aling-Aling Waterfall belum berjalan dengan baik sehingga perlu dilakukan penelitian yang lebih mendalam. Hal tersebut sesuai dengan hasil penelitian terdahulu oleh(Negara, 2019) menyebutkan bahwa penting untuk menerapkan prinsip akuntabilitas dan transparansi dalam pengelolaan dana di Vihara demi menjaga kepercayaan dari seluruh umat di vihara sehingga terciptanya keharmonisan, selain itu menurut(Khairizah, Noor, \& Suprapto, 2015) akuntabilitas adalah kewajiban agen (pemerintah) untuk mengelola sumber daya, melaporkan, dan mengungkapkan segala aktivitas dan kegiatan yang berkaitan dengan penggunaan sumber daya publik kepada pemberi mandat (prinsipal).

Berdasarkan uraian latar belakang yang di paparkan di atas, adapun rumusan masalah yang disusun yaitu : (1) Bagaimana sistem pencatatan aliran kas masuk dan keluar pada Objek Wisata Aling-Aling Waterfall di Desa Sambangan? dan (2) Bagaimana praktik akuntabilitas dan transparansi dalam pengelolaan keuangan Objek Wisata Aling-Aling Waterfall di Desa Sambangan? Dan (3) Bagaimana alur proses pengelolaan keuangan pada objek wisata air terjun Aling-Aling Waterfall di Desa Sambangan?

\section{Metode}

Penelitian ini menggunakan metode kualitatif. Menurut (Nasution S., 1988) Penelitian Kualitatif adalah mengamati orang dalam lingkungan, berinteraksi dengan mereka, dan menafsirkan pendapat mereka tentang dunia sekitar. Penelitian ini dilakukan pada Kelompok Aling-Aling Desa Sambangan sebagai pengelola Objek Wisata Aling-Aling Waterfall. 
Subjek dari penelitian ini yang pertama adalah Ketua Kelompok Aling-Aling guna meminta ijin untuk melakukan penelitian, memperoleh informasi mengenai sejarah pengelolaan objek dan struktur organisasi. Subjek yang kedua adalah Bendahara Kelompok Aling-Aling untuk memperoleh informasi mengenai sistem dan alur pengelolaan keuangan objek serta pertanggungjawabannya. Subjek yang ketiga adalah Ketua BUMDes Giri Amertha guna memperoleh informasi mengenai pertanggungjawaban yang dilakukan oleh pengelola objek wisata di Desa Sambangan. Sumber data yang digunakan dalam penelitian ini adalah data primer yaitu wawancara dan data sekunder berupa dokumen, catatan mengenai pengelolaan keuangan Objek Wisata Aling-Aling Waterfall. Metode pengumpulan data yang digunakan dalam penelitian ini diantaranya: metode wawancara, observasi, dan studi dokumentasi. Dalam penelitian ini peneliti melakukan observasi pada alur pencatatan pendapatan dan pengeluaran kas dari Objek Wisata Air Terjun Aling-Aling dan proses pengelolaan keuangan hingga pertanggung jawabannya. Peneliti juga melakukan studi dokumentasi yaitu mempelajari berbagai dokumen yang terkait dengan aktivitas pengelolaan keuangan Kelompok Aling-Aling. Metode penelitian yang digunakan pada penelitian ini adalah metode kualitatif.Analisis data yang digunakan dalam penelitian ini adalah analisis data interaktif $\mathrm{Mi}$ les dan Huberman (1984). Tahapan analisis data terdiri atas 1)Reduksi data, 2)penyajian data dan 3)penarikan kesimpulan.

\section{Hasil dan Pembahasan}

Sistem pencatatan aliran kas masuk dan keluar pada Objek Wisata Aling-Aling Waterfall di Desa Sambangan

Sistem pencatatan aliran kas masuk dan aliran kas keluar pada pengelolaan Objek Wisata Aling-Aling Waterfall yang dilakukan oleh Kelompok Aling-Aling dapat dikatakan masih sederhana dan belum dipisahkan antara buku kas masuk dan keluar. Pencatatan kas masuk yang dilakukan oleh Kelompok Aling-Aling dimulai dari pencatatan hasil pendapatan penjualan tiket kunjungan yang dilakukan setiap hari. Hasil penjualan tiket kunjungan tersebut diterima oleh Kelompok Aling-Aling dari pihak TIC (tourist information center) yang bertugas menjual tiket kunjungan ke wisatawan yang berkunjung. Pencatatan kas masuk yang dilakukan oleh Kelompok Aling-Aling sejauh ini hanya mencatat penerimaan pendapatan, hal tersebut dikarenakan tidak ada aktivitas lain yang dapat menambah kas selain pendapatan. Selanjutnya, jumlah kas masuk yang dicatat setiap hari tersebut akan ditotalkan dalam waktu satu bulan untuk mengetahui jumlah ataupun total kas masuk selama satu bulan. Untuk pencatatan kas keluar sama dengan pencatatan kas masuk yakni pengeluaran dicatat setiap hari dan jumlahnya akan ditotalkan selama satu bulan untuk mengetahui jumlah kas keluar selama satu bulan. Pengeluaran kas tersebut digunakan untuk kegiatan operasional seperti pembayaran ongkos jaga, pembayaran listrik, pembayaran ongkos sampah, pembelian tisu toilet dan lain sebagainya. Pemaparan tersebut sesuai dengan hasil wawancara dengan Bendahara Kelompok Aling-Aling yaitu Bapak Ketut Toya sebagai berikut :

"Untuk pencatatan kas masuk ada buku pencatatan untuk kas masuk dan kas keluar namun belum saya pisahkan antara buku kas masuk dan kas keluar. Untuk kedepannya akan diusahaakan agar pencatatan kas masuk dan keluar agar dicatat pada buku pencatatan yang berbeda agar lebih mudah. Penerimaan pendapatan dicatat setiap hari, begitu juga pengeluaran. Penerimaan hasil penjualan tiket tersebut sudah termasuk didalamnya nomor seri, jumlah kunjungan, wisatawan asing maupun lokal jumlahnya sekian. Untuk pengeluaran berupa pembayaran ongkos jaga, pembelian tisu toilet, pembayaran ongkos sampah, pembayaran listrik." 
Praktik akuntabilitas dan transparansi dalam pengelolaan keuangan Objek Wisata AlingAling Waterfall di Desa Sambangan.

Akuntabilitas dan Transparansi merupakan bagian dari teori good corporate governance (tata kelola perusahaan yang baik). Kedua prinsip tersebut merupakan hal yang penting dalam penyelenggaraan suatu pengelolaan keuangan disetiap organisasi atau lembaga, baik organisasi pemerintah maupun organisasi non pemerintah. Dalam penelitian ini terdapat indikator-indikator yang dijadikan peneliti untuk mengetahui akuntabilitas dalam pengelolaan keuangan Objek Wisata Aling-Aling Waterfall, indikator akuntabilitas tersebut yaitu : (a) Adanya kesesuaian antara pelaksanaan dan standar prosedur pelaksanaan, (b) Tercapainya tujuan dalam pengelolaan keuangan, (c) Adanya pengawasan dalam pengelolaan keuangan dan (d) Adanya laporan pertanggungjawaban.

Standar prosedur pelaksanaan dalam pengelolaan keuangan Objek Wisata AlingAling Waterfall berdasarkan hasil kesepakatan dari pertemuan antara Kelompok Aling-Aling, pokdarwis dan BUMDes pada tahun 2018 dalam beberapa kali pertemuan. Hasil dari beberapa kali pertemuan tersebut menghasilkan kesepakatan berupa besaran presentase dari hasil pendapatan Objek Wisata Aling-Aling Waterfall ke masing-masing organisasi atau kelompok. Pada saat itu karena ketua dari pokdarwis mengundurkan diri dari jabatan dan mengakibakibatkan kekosongan kepemimpinan di pokdarwis, sehingga pengelolaan diambil alih oleh BUMDes, setelah itu pengelolaan diserahkan ke Kelompok Aling-Aling. Pengalihan tersebut tidak ada peraturan yang mendasari, oleh karena BUMDes tidak boleh langsung mengelola unit usaha.

Tercapainya tujuan dalam pengelolaan keuangan Objek Wisata Aling-Aling Waterfall tercermin dari kesejahteraan dari masing-masing anggota kelompok. Tidak hanya anggota kelompok saja, masyarakat di kawasan Objek Wisata Aling-Aling Waterfall juga ikut merasakan dampak baik dari pengelolaan keuangan Objek Wisata Aling-Aling Waterfall seperti contoh ketika ada warga yang bertempat tinggal di sekitaran kawasan Objek Wisata Aling-Aling Waterfall memiliki atau sedang menggelar upacara adat/keagamaan, Kelompok Aling-Aling memberikan sejumlah dana yang merupakan dana sosial. Dana sosial tersebut telah direncanakan sebelumnya oleh bendahara. Pemaparan tersebut sesuai dengan hasil wawancara dengan Bendahara Kelompok Aling-Aling yaitu Bapak Ketut Toya sebagai berikut :

"Tujuan dari pengelolaan keuangan ini tidak lain dan tidak bukan adalah untuk mensejahterakan anggota kelompok pada khususnya dan warga masyarakat yang bertempat tinggal di sekitar kawasan aling-aling pada umumnya. Untuk anggota kelompok, setiap bulannya akan memperoleh uang kesejahteraan dan untuk masyarakat jika sedang memiliki upacara agama, Kelompok Aling-Aling telah mengatur tentang pengalokasian dana sosial bagi masyarakat yang memiliki upacara".

Pengelolaan keuangan Objek Wisata Aling-Aling Waterfall ini diawasi oleh BUMDes dan pokdarwis. Pengawasan yag dilakukan baik oleh BUMDes maupun pokdarwis yakni secara rutin memeriksa hasil penjualan tiket kunjungan yang dikelola oleh Kelompok AlingAling. Untuk laporan keuangan yang disusun oleh Kelompok Aling-Aling akan menjadi pertanggungjawaban pengurus kepada seluruh anggota kelompok ataupun pihak yang memerlukan informasi. Pertanggungjawaban yang dilakukan biasanya setiap setelah menggelar suatu kegiatan seperti contoh piodalan di Objek Wisata Aling-Aling Waterfall, penataan atau membuat wahana baru di Objek Wisata Aling-Aling Waterfall. Pemaparan tersebut sesuai dengan hasil wawancara dengan Bapak Made Sutama selaku ketua Kelompok Aling-Aling sebagai berikut : 
"Untuk di kelompok, kita terbuka saja dik, transparan dan akuntable saja. Pelaporan pertanggungjawaban ke anggota disampaikan pada saat rapat. Untuk ke pihak BUMDes karena tidak diatur secara tertulis, kami tidak melaporkan namun tetap mengalokasikan hasil pendapatan ke BUMDes sesuai presentase. Untuk lebih rincinya bisa ditanyakan ke bendahara".

Pernyataan senada juga dipaparkan oleh Bapak Ketut Toya selaku Bendahara Kelompok Aling-Aling sebagai berikut :

"Pertanggungjawaban pengelolaan keuangan ke anggota biasanya dilaksanakan setiap 6 bulan atau akhir tahun dan juga pada saat selesai menggelar sebuah acara disampaikan saat rapat. Untuk pelaporan ke BUMDes kami tetap menyetor data penjualan karcis, tanda terima semua ada".

Selain akuntabilitas, transparansi juga sangat penting dilakukan dalam pengelolaan keuangan Objek Wisata Aling-Alling Waterfall. Dalam penelitian ini terdapat indikatorindikator yang dijadikan pedoman peneliti untuk mengetahui transparansi dalam pengelolaan keuangan Objek Wisata Aling-Aling Waterfall, indikator transparansi tersebut antara lain : (a) Adanya informasi yang mudah dipahami, (b) Keterbukaan informasi/dokumen pengelolaan keuangan, (c) Keterbukaan proses pengelolaan keuangan dan (d) Adanya musyawarah yang melibatkan masyarakat.

Transparansi di dalam praktek pengelolaan keuangan Objek Wisata Aling-Aling Waterfall diwujudkan dalam sebuah pertemuan yang telah direncanakan setiap bulan. Dalam pertemuan tersebut dibahas mengenai informasi tentang keuangan dan kegiatan dari Kelompok Aling-Aling. Selain dari pertemuan yang direncanakan digelar setiap bulannya, Kelompok Aling-Aling rutin meggelar rapat dengan seluruh anggota kelompok setiap enam bulan atau setiap akhir tahun guna menyampaikan kondisi keuangan, penyampaian pertanggungjawaban setelah menggelar kegiatan serta rencana kegiatan yang akan dilaksanakan untuk kedepannya. Pemaparan tersebut sesuai dengan hasil wawancara dengan Bapak Made Sutama selaku ketua Kelompok Aling-Aling sebagai berikut :

"Untuk di kelompok mengenai soal keuangan kita terus terang transparan saja, setiap menggelar kegiatan kita pasti sampaikan ke anggota berapa dana yang diperlukan. Untuk ke pihak atau kelompok lainnya kita selalu siap jika nantinya ada pihak yang memerlukan informasi mengenai pengelolaan aling-aling."

Pernyataan senada juga dipaparkan oleh Bapak Ketut Toya selaku Bendahara Kelompok Aling-Aling sebagai berikut :

"Untuk penyampaian segala informasi ke anggota, direncanakan pertemuan setiap bulannya untuk menyampaikan entah itu kegiatan, posisi keuangan kelompok, untuk masalah keterbukaan informasi kita selalu siap, siapapun yang memerlukan informasi mengenai pengelolaan aling-aling kami siap memberikan informasi. Untuk penyampaian ke masyarakat desa diluar kelompok, diselenggarakan dalam musdes (musyawarah desa) Kelompok Aling-Aling diwakili oleh BUMDes sebagai wadah unit usaha di Desa Sambangan".

Alur proses pengelolaan keuangan pada Objek Wisata Aling-Aling Waterfall di Desa Sambangan

Dalam alur mekanisme pengelolaan keuangan Objek Wisata Aling-Aling Waterfall, BUMDes yang bertugas mengeluarkan tiket kunjungan, kemudian yang bertugas dalam 
menjual tiket tersebut adalah petugas TIC (Tourist Information Centre). Petugas TIC (Tourist Information Centre) ini berasal dari pokdarwis yang setiap harinya menjual tiket di countre kepada wisatawan yang berkunjung, baik wisatawan lokal maupun asing. Tiket kunjungan menuju Objek Wisata Aling-Aling Waterfall tersebut dijual Rp. 20.000/lembar. Pendapatan dari hasil penjualan tiket kunjungan ini setiap harinya akan disetorkan oleh petugas TIC kepada Bendahara Kelompok Aling-Aling yang kemudian akan dikelola. Dalam sepekan, Bendahara Kelompok Aling-Aling akan menyetorkan ke BUMDes sesuai dengan presentase yang telah disepakati bersama. Pemaparan tersebut sesuai dengan hasil wawancara dengan Bapak Ketut Toya selaku Bendahara Kelompok Aling-Aling sebagai berikut :

"Untuk alur proses pengelolaan keuangan Objek Wisata Aling-Aling Waterfall, dimulai dari dikeluarkannya tiket kunjungan oleh BUMDes sebagai organisasi yang sah, kemudian tiket ataupun karcis tersebut dijual oleh petugas TIC (Tourist Information Centre) kepada wisatawan yang berkunjung seharga Rp. 20.000/lembar. Hasil dari pendapatan penjualan tiket tersebut nantinya setiap hari akan disetor ke Saya dan nantinya Saya akan menyetorkan ke BUMDes sesuai dengan presentase sesuai kesepakatan pada saat pertemuan".

Pernyataan senada juga dipaparkan oleh Bapak Made Sutama selaku Ketua Kelompok Aling-Aling sebagai berikut :

"Mula-mulanya dalam proses pengelolaan keuangan Aling-Aling itu dimulai dari pemasukkan, nah pemasukkan tersebut berasal penjualan tiket dik, yang bertugas menjual tiket tersebut adalah orang-orang dari pokdarwis dan nantinya diserahkan pendapatan tersebut ke bendahara kita. Untuk lebih rincinya bisa ditanyakan ke bendahara".

Berdasarkan pemaparan hasil penelitian dari wawancara dengan informan di atas dan studi dokumentasi, alur proses pengelolaan keuangan Objek Wisata Aling-Aling Waterfall secara sederhana dapat digambarkan sebagai berikut.

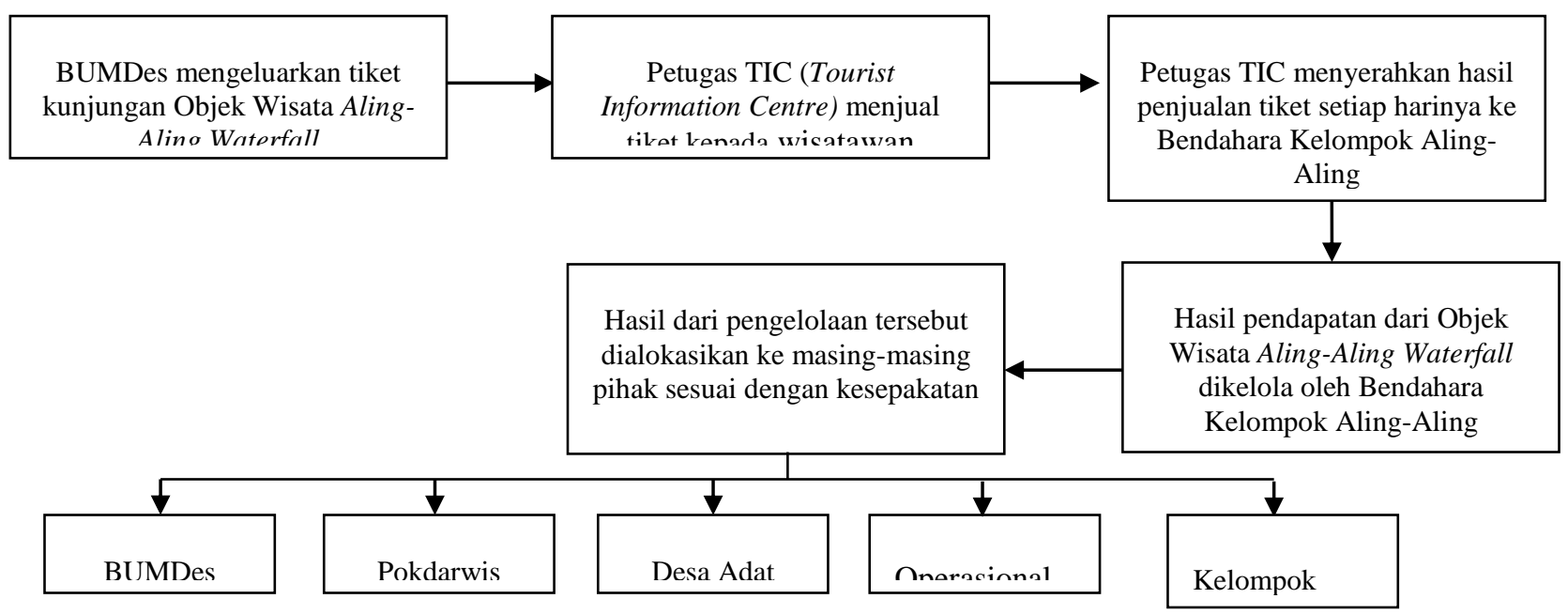

Gambar1. Alur proses pengelolaan keuangan Objek Wisata Aling-Aling Waterfal

(Sumber : Kelompok Aling-Aling, 2020)

\section{Simpulan dan Saran}

Berdasarkan dari hasil penelitian pada akuntabilitas dan transparansi pengelolaan keuangan Objek Wisata Aling-Aling Waterfall sebagai pendapatan tambahan Desa Sambangan, dapat disimpulkan bahwa yang pertama yaitu pencatatan kas masuk pada Objek 
Wisata Aling-Aling Waterfall dilakukan oleh Bendahara Kelompok Aling-Aling ketika hasil dari penjualan tiket kunjungan wisatawan diserahkan oleh pihak TIC (tourist information center) setiap harinya. Pencatatan kas masuk dan keluar masih bersifat sederhana, pencatatan aliran kas masuk dan kas keluar masih dilakukan dalam satu buku pencatatan, untuk kedepannya Bendahara Kelompok Aling-Aling akan menggunakan buku pencatatan yang berbeda. Yang kedua mengenai akuntabilitas di dalam pengelolaan keuangan Objek Wisata Aling-Aling Waterfall di tujukkan melalui tercapainya tujuan dalam pengelolaan keuangan yaitu meningkatnya kesejahteraan anggota kelompok pada khususnya dan masyarakat pada umumnya. Pengelolaan keuangan Objek Wisata Aling-Aling Waterfall diawasi oleh BUMDes dan pokdarwis yang sewaktu-waktu dapat meminta keterangan kepada Kelompok Aling-Aling terkait pengelolaan keuangan. Sedangkan transparansi di dalam pengelolaan keuangan Objek Wisata Aling-Aling Waterfall di tujukkan melalui penyampaian informasi kepada seluruh anggota pada saat rapat atau pertemuan yang telah direncanakan setiap bulannya. Untuk pihak dari luar kelompok, Kelompok Aling-Aling senantiasa bersedia memberikan informasi terkait pengelolaan Objek Wisata Aling-Aling Waterfall, dan yang terakhir mengenai alur proses pengelolaan keuangan pada Objek Wisata Aling-Aling Waterfall dimulai dari dikeluarkannya tiket kunjungan wisatawan oleh BUMDes, kemudian diserahkan kepada pihak TIC (tourist information centre) untuk dijual ke wisatawan, selanjutnya hasil penjualan tiket tersebut akan disetor kepada Bendahara Kelompok AlingAling setiap hari. Hasil penjualan tiket tersebut akan dikelola oleh Bendahara Kelompok Aling-Aling sebelum dialokasikan ke masing-masing pihak sesuai persentase.

Berdasarkan hasil dari penelitian yang telah dilaksanakan dan dikaitkan dengan tujuan dan manfaat penelitian yang telah diungkapkan sebelumnya, Maka terdapat beberapa saran yang bisa peneliti sampaikan yang pertama yaitu kepada seluruh kelompok atau organisasi yang terlibat dalam pengelolaan Objek Wisata Aling-Aling Waterfall, hendaknya menggelar sebuah pertemuan dengan pemerintah desa ataupun organisasi atau kelompok yang mewakili yakni BUMDes untuk membuat suatu peraturan tertulis yang jelas mengenai status dari masing-masing kelompok, pelaporan yang harus dilakukan oleh masing-masing kelompok, agar terciptanya pengelolaan objek wisata yang professional karena berdasarkan observasi di lapangan, masih banyak ditemukan hal yang belum diatur secara tertulis dalam pengelolaan pariwisata di Desa Sambangan sehingga terkadang mengakibatkan perselisihan-perselisihan anatara individu atau kelompok yang terlibat dalam pengelolaan pariwisata di Desa Sambangan. Dengan dibuatnya peraturan secara tertulis mengenai pelaporan pertanggungjawaban pengelola objek wisata oleh BUMDes, Kelompok Aling-Aling maupun kelompok lainnya tidak akan bingung ketika akan membuat laporan pertanggungjawaban, format laporan pertanggungjawabannya seperti apa dan kepada pihak mana pengelolaan objek wisata tersebut harus dipertanggungjawabkan agar menjadi lebih jelas untuk kedepannya.

\section{Daftar Pustaka}

Ahmad, A. W., \& Septriani, Y. (2008). Konflik Keagenan: Tinjauan Teoritis dan Cara Menguranginya. Jurnal Akuntansi Dan Manajemen, 3(2), 47-56.

Hehanussa, S. J. (2015). kutip 1 (Salomi J. Hehanussa ). Conference in Busniess, Accounting and Management, 2, 82-90.

Khairizah, A., Noor, I., \& Suprapto, A. (2015). Pengaruh gaya kepemimpinan terhadap kinerja karyawan (studi pada karyawan di Perpustakaan Universitas Brawijaya Malang). Jurnal Administrasi Publik (JAP), 3(7), 1268-1272.

Nasution S. (1988). Qualitative Naturalistic Research Method. 
Negara, I. K. D. A. (2019). Analisis Pengelolaan Dana Abadi Sebagai Bentuk. (45), 251262.

Miles, M.B \& Huberman A.M. 1984, Analisis Data Kualitatif. Terjemahan oleh Tjetjep Rohendi Rohidi. 1992. Jakarta : Penerbit Universitas Indonesia.

Octalianna, \& Rahayuningsih, D. A. (2013). Analisis Kepemilikan Managerial Berbasis Pada Teori Keagenan. Jurnal Bisnis Dan Akuntansi, 15(1), 65-72.

Sukmawati, F., Pujiningsih, S., \& Laily, N. (2016). Akuntabilitas Gereja dalam Perspektif Alkitabiah dan Stewardship Theory (Study Kasus pada Gereja X di Jawa Timur). Jurnal Akuntansi Aktual, 3, 301-310. 